\title{
Treatment of excessive gingival display using modified lip reposi- tioning technique with esthetic crown lengthening: Case reports
}

\author{
Gwi-Hyeon Min ${ }^{1}$, Sang-Joun Yu ${ }^{1,2}$, Byung-Ock Kim ${ }^{1,2}$, and Won-Pyo Lee ${ }^{1,2 *}$ \\ ${ }^{1}$ Department of Periodontology, School of Dentistry, Chosun University, Gwangju 61452, Republic of Korea \\ ${ }^{2}$ Oral Biology Research Institute, Chosun University, Gwangju 61452, Republic of Korea
}

(Received Apr 23, 2018; Revised version received May 17, 2018; Accepted May 29, 2018)

\begin{abstract}
Excessive gingival display that can be seen when a person smiles can cause non-esthetic problem. This gummy smile is mainly caused by an altered passive eruption, bony maxillary excess, and excessive maxillary lip mobility. Thus far, an altered passive eruption has been successfully treated using esthetic crown lengthening. Recently, an alternative to orthognathic surgery has been proposed for the treatment of a gummy smile. Studies using a lip repositioning procedure have actively been performed. In this report, we present three cases of treatment for excessive gingival display using the modified lip repositioning technique associated with esthetic crown lengthening.
\end{abstract}

KEY WORDS: Crown lengthening, Esthetics, Gummy smile, Lip repositioning

\section{서 론}

웃을 때 전반적인 과도한 치은 노출은 심미적 관점에서 문제가 될 수 있다. 이러한 상태는 "gummy smile "로 불 리며, $10.5 \%[1]$ 에서 $29 \%[2]$ 까지 높은 유병률이 보고되고 있다. 과도한 치은 노출은 남성보다는 여성에게서 더 관찰 되며, 비심미적으로 여겨진다[3].

Gummy smile의 주요 원인으로는 변형된 수동적 맹출[4], 수직적인 상악골 과성장[5], 미소 시 상순의 과활성도[6] 등이 있다. 치아는 악골 내에서 기능적인 교합에 도달할 때까지 능동적 맹출 과정을 거친 후, 부착 기구의 근단 방 향 이동이 발생하는 수동적 맹출 과정을 거치게 된다. 이 러한 수동적 맹출이 완전히 일어나지 않는 경우를 변형된 수동적 맹출이라고 한다[7]. 변형된 수동적 맹출은 과도한 치은노출뿐만 아니라 상악전치부에서 짧은 치관을 야기하 므로, Coslet 등[4]은 각화 치은의 양과 치조정의 위치에 따라 다양한 치주 수술을 선택적으로 활용한 심미적 치관

*Corresponding author: Won-Pyo Lee

Department of Periodontology, School of Dentistry, Chosun University, 309 Pilmun-daero, Dong-gu, Gwangju 61452, Republic of Korea

Tel.: +82-62-220-3850, Fax: +82-62-224-4664

E-mail: wplee8@chosun.ac.kr
연장술을 통해 성공적으로 치료할 수 있음을 보고하였다. 또한, 수직적인 상악골 과성장 및 상순의 과활성도에 의한 과도한 치은 노출의 경우에는 입술 재위치술을 통해 예지 성 있는 심미적 개선 효과를 얻을 수 있다[8]. 입술 재위 치술은 Rubenstein과 Kostianovsky[9]에 의해 1973년에 처 음으로 보고되었음에도 불구하고, 최근 들어서야 gummy smile 치료를 위한 악교정 수술의 하나의 대안으로 다시 활발히 연구 되고 있다[10-14]. Silva 등[15]은 상악 순소대 까지 제거하는 기존의 술식의 단점을 보완한 변형된 입술 재위치술을 처음으로 소개하였으며, 이 술식이 보다 덜 침 습적이면서 성공적인 치은 노출 개선효과가 있음을 보고 하였다.

이번 연구에서는 미소 시 과도한 치은 노출을 보이는 환 자에게서 변형된 입술 재위치술과 심미적 치관연장술을 사용하여 심미적 문제점을 개선한 세 가지 증례에 관하여 보고하고자 한다.

\section{증례보고}

\section{증례 1}

35세 여성 환자로 웃을 때 치은의 과도한 노출이 보기 싫다는 주소로 내원하였다. 전신질환은 없었으며, 1 년 전 개인치과에서 치은절제술을 통한 심미적 치관연장술을 시 


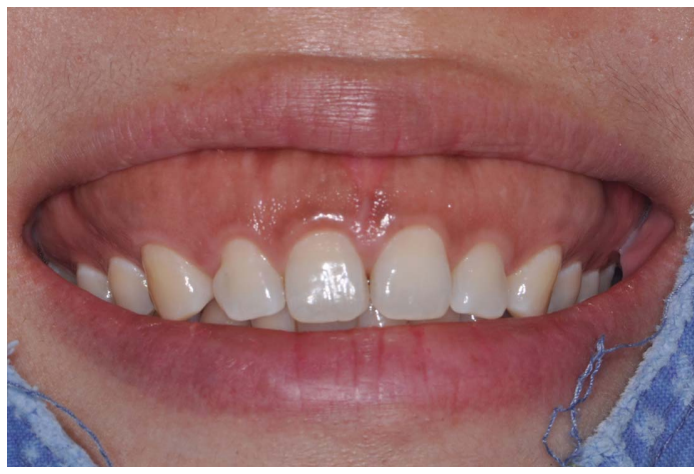

Fig. 1. Preoperative imaging of the dynamic smile.

행한 치과병력이 있었다. 수직적인 상악골 과성장 및 상순 의 과활성도에 의해 미소 시 $8 \mathrm{~mm}$ 정도의 치은 노출이 관 찰되었다(Fig. 1). 환자는 악교정 수술 및 심미적 치관연장 술보다는 입술 재위치술 치료를 먼저 받기를 원하여 기존 의 술식 보다 덜 침습적인 Silva 등[15]이 처음 제시한 변 형된 입술 재위치술을 시행하기로 결정하였다.

국소마취 하에, 상악 순소대를 중심으로 양쪽에 두 개의 직사각형 모양의 $1 \mathrm{~mm}$ 깊이의 부분층 절개를 시행하였다 (Fig. 2A). 즉, 치관측 수평 절개는 각화치은을 약 $1 \mathrm{~mm}$ 정 도 포함하면서 순소대 부위에서 상악 제 1대구치 부위까지 시행하였다. 치관 측 수평 절개의 양 끝에서 시행하는 수직 절개는 일반적으로 미소 시 노출되는 치은양의 두 배만큼의
길이로 치근방향으로 절개한다. 이 환자의 경우에는 치은노 출양이 $8 \mathrm{~mm}$ 정도로 대략 $16 \mathrm{~mm}$ 길이의 수직 절개를 시행 하였다. 마지막으로, 치근방향으로 가해진 수직 절개 끝점들 을 이어, 치근측 수평 절개를 완성하였다. 이렇게 도식화된 양쪽 치조점막띠를 $1 \mathrm{~mm}$ 두께의 부분층 판막을 형성하여 제거하였다(Fig. 2B). 이 때, 변형된 입술 재위치술의 경우에 는 상악 순소대를 제거하지 않는다. 치조점막띠 제거 후 하 방에는 결합조직층이 노출되었다(Fig. 2C). 이후 치근측 수 평 경계를 봉합사(Dafilon 6/0, B.Braun Surgical SA, Barcelona, Spain)를 이용하여 단순봉합함으로써 치관측 수평경계쪽으 로 치관 변위하여 안정화시켰다(Fig. 2D). 수술 후에는 진통 제(Aclofen Tab. 100 mg, Dong-A Pharm., Seoul, Korea)를 하 루에 2회씩 3일 동안 처방하였으며, 2주 동안 $0.12 \%$ 헥사메 딘 가글을 하루에 2 회씩 하도록 교육하였다. 또한 수술 후 2 주 동안은 웃을 때나 또는 말할 때 가해질 수 있는 수술부위 의 기계적 자극을 최소화 하도록 지시하였다.

수술 2주 후 발사하였으며 이 시기에는 미소 시 치은 노 출이 관찰되지 않았다(Fig. 3A). 수술 3개월 후 미소 시 치 은노출양은 $2 \mathrm{~mm}$ 로 재발 경향이 관찰되었다. 하지만 수 술 12 개월 후에도 미소 시 $2 \mathrm{~mm}$ 정도 치은 노출이 관찰 되어 입술 위치가 안정화된 상태를 보였다(Fig. 3B).

\section{증례 2}

26세 여성 환자로 상악 전치부 치아가 짧고(Fig. 4A), 웃
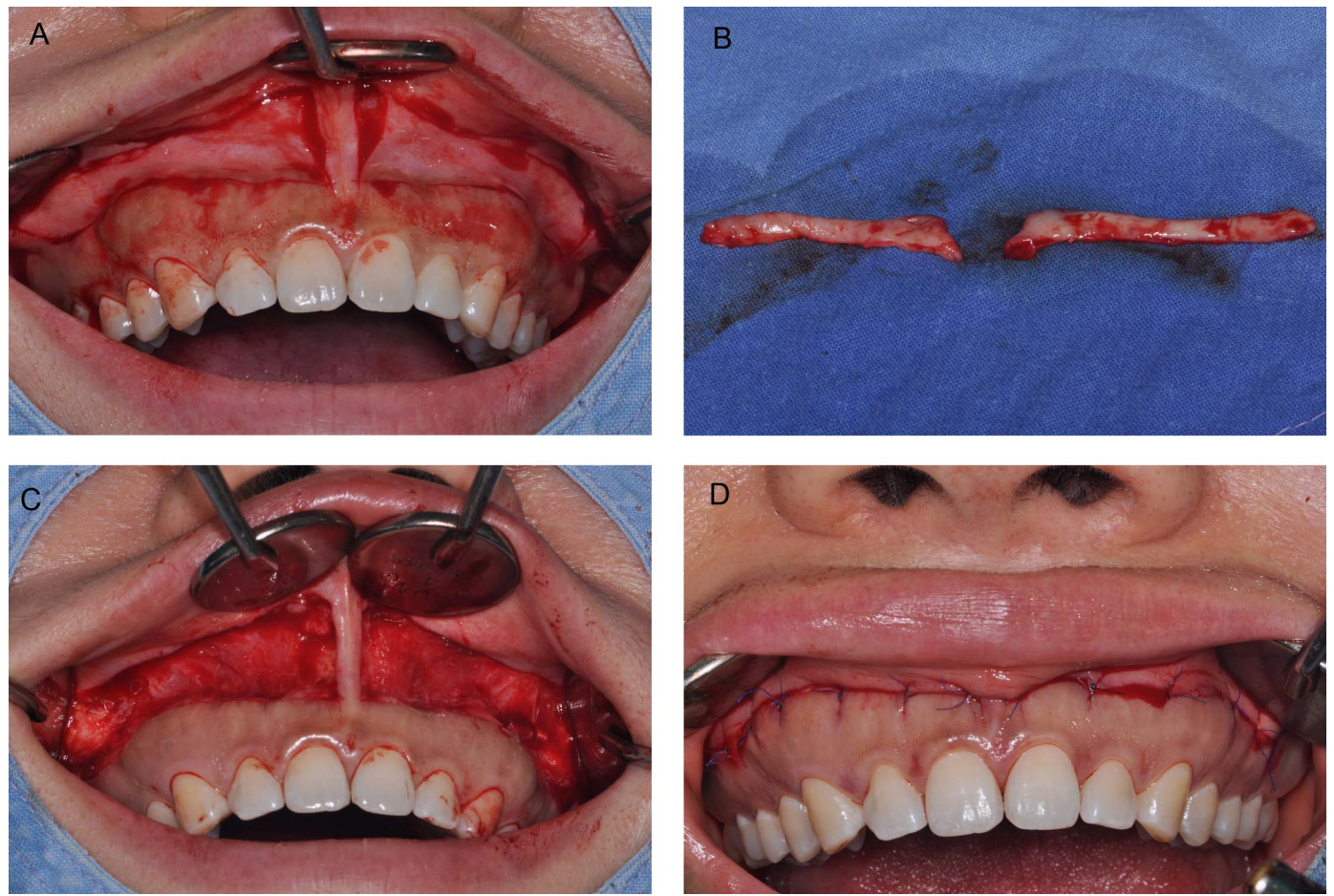

Fig. 2. (A) Incision design, (B) the removed strip of outlining mucosa, (C) exposed connective tissue, and (D) mucosa positioned and sutured. 

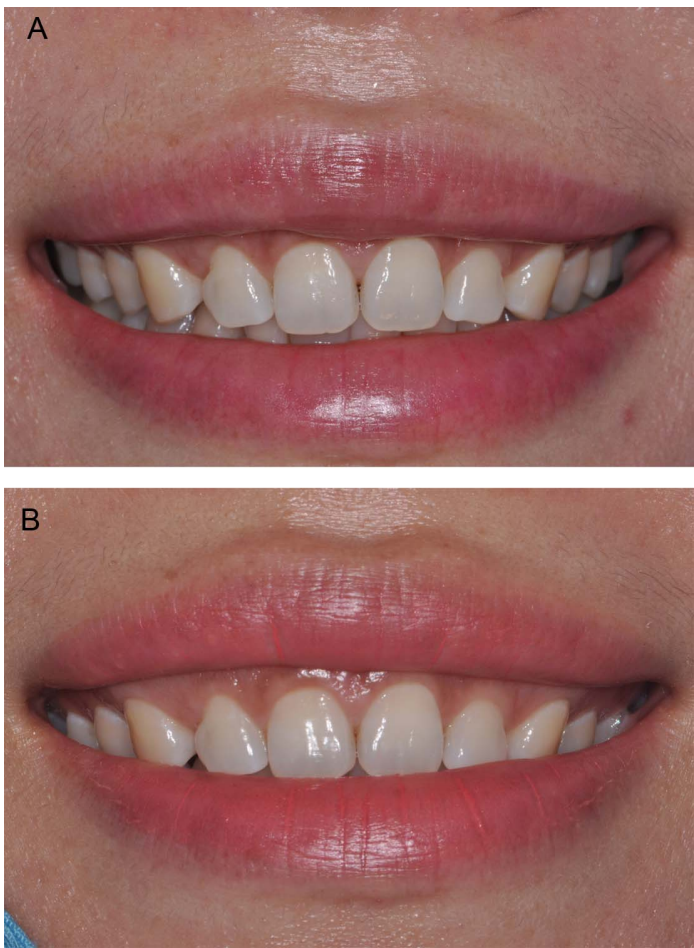

Fig. 3. (A) Two weeks postoperative visit and (B) twelve months postoperative visit showing good stability of result.
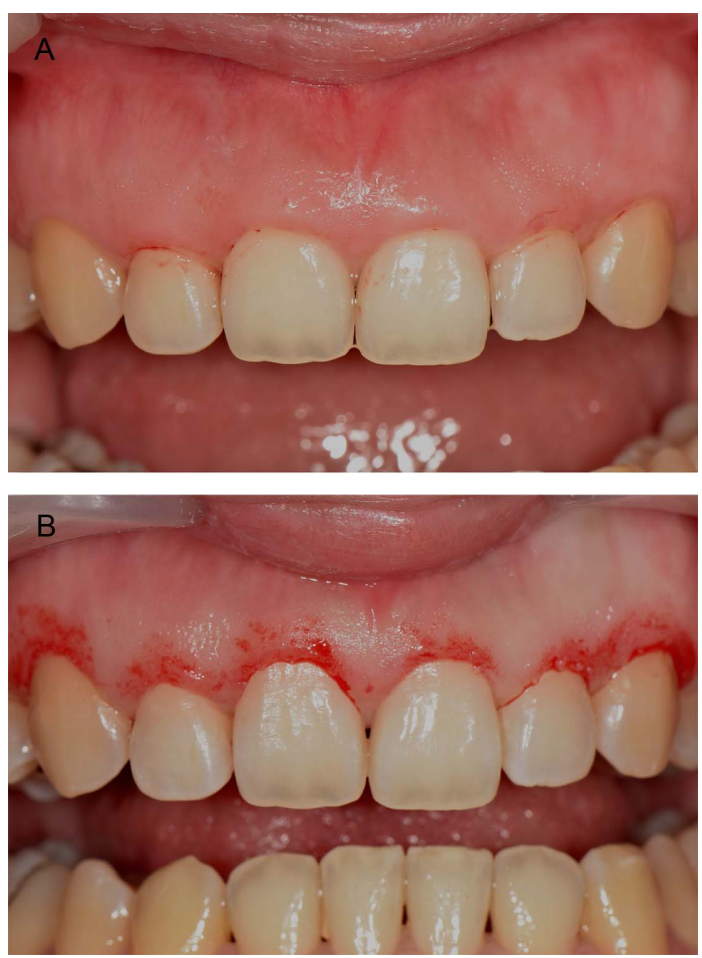

Fig. 4. (A) Pre-treatment and (B) immediately after gingivectomy.

을 때 치은 노출이 심하다는 주소로 내원하였다. 전신질환 은 없었으며 본원 치주과 수련의가 상악 6 전치의 심미적 치관 연장술을 시행하기로 계획하였다. 본원 치주과 수련
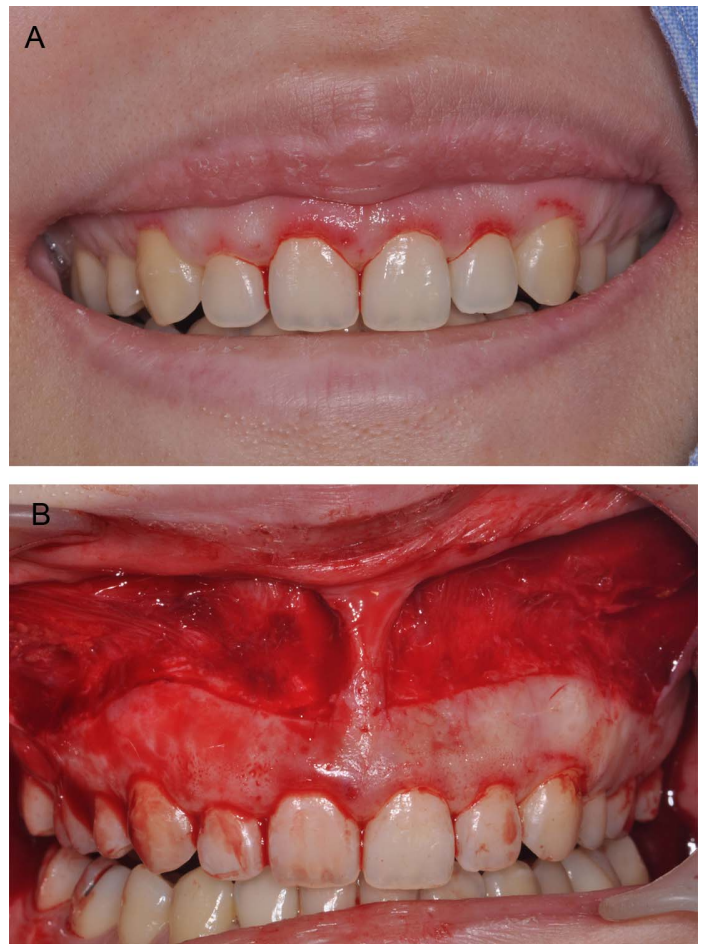

Fig. 5. (A) Preoperative image of the dynamic smile and (B) mucosal strips removed after gingivectomy.
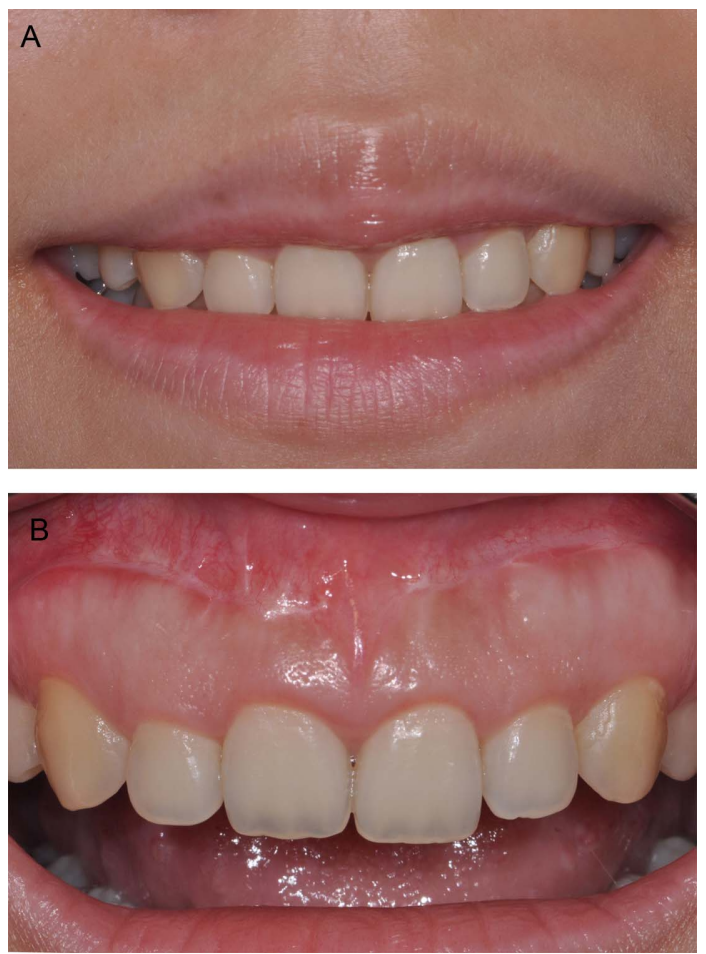

Fig. 6. (A) Extraoral view 3 months after surgery and (B) intraoral view 3 months after surgery.

의는 변형된 수동적 맹출의 type I subgroup $\mathrm{A}[4]$ 로 진단 하여 치은절제술을 시행하였다(Fig. $4 \mathrm{~B}$ ). 치은절제술 시행 
1 주 후 환자분이 입술 재위치술을 받기를 원하시어 술자 에게 의뢰되었다. 수직적인 상악골 과성장 및 상순의 과활 성도에 의해 웃을 때 $4 \mathrm{~mm}$ 정도의 치은 노출이 관찰되었 으며, 1 주일 전 본원 수련의가 시행한 치은절제술 후 재발 경향이 일부 관찰되었다(Fig. 5A). 따라서 Gummy simile 치료를 위해 변형된 입술 재위치술 및 동시에 치은절제술 을 재시행하였다(Fig. 5B). 변형된 입술 재위치술 시행 3 개월 후 미소 시 치은노출양은 없었으며(Fig. 6A), 치은절 제술 후 길어지고 조화로운 임상 치관 형태에 의해 심미 성이 향상된 것을 관찰할 수 있었다(Fig. $6 \mathrm{~B}$ ).

\section{증례 3}

31세 여성 환자로 웃을 때 치은 노출이 심하고, 상악 견 치가 짧다는 주소로 내원하였다. 전신질환은 없었으며 임 상검사결과 미소 시 상악 중철지 부위에서 $3 \mathrm{~mm}$ 정도의 치은 노출이 있었다(Fig. 7A). 또한 술 전 치주낭 깊이는 $1 \sim 3 \mathrm{~mm}$ 로 정상 범위였으며, 각화 치은의 폭경은 $6 \sim 7 \mathrm{~mm}$ 로 충분한 양을 갖고 있었다. 탐침 시 치조정의 위치가 백악법랑 경계에 근접하여 변형된 수동적 맹출 type I subgroup $\mathrm{B}[4]$ 로 진단하였다(Fig. 7B). 따라서 변형된 입술 재위치술 및 골 절제술을 동반한 치은절제술을 계획하였다. 하지만 환자분 이 골절제술을 원하지 않은 결과, 변형된 입술 재위치술과 단지 치은절제술만을 먼저 시행하였다(Fig. 8). 수술 3개월 후 미소 시 상악 중철치부위의 치은노출은 관찰되지 않았
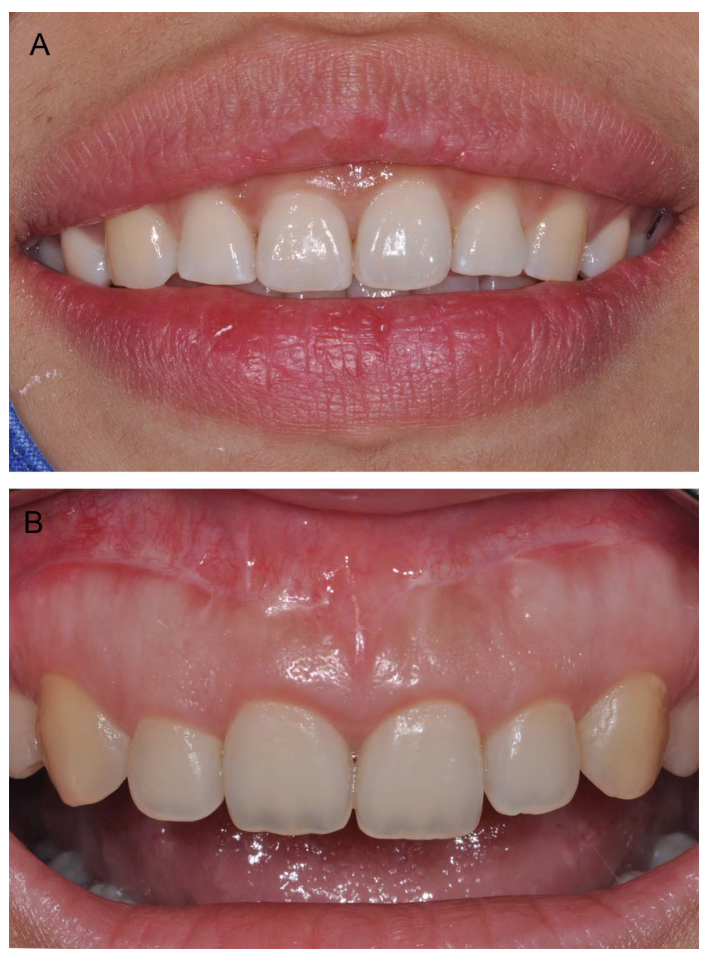

Fig. 7. (A) Preoperative image of the dynamic smile and (B) intraoral view before surgery.

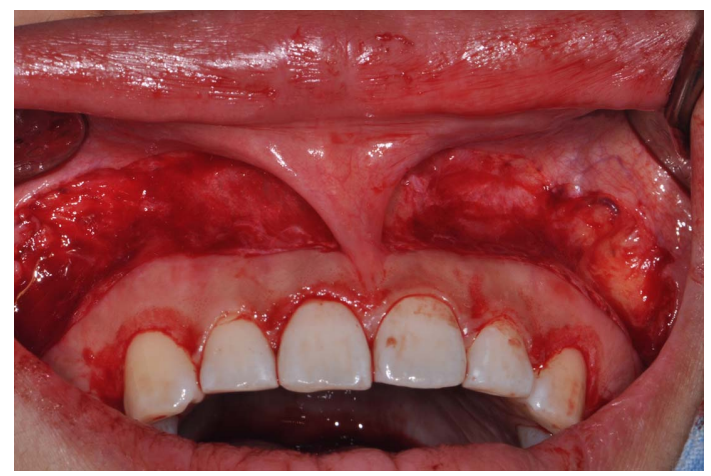

Fig. 8. Mucosal strips removed after gingivectomy.

으나, 우측 중절치와 좌측 견치 부위에 치은절제술 후 재 발 경향이 관찰되었다(Fig. 9A and 9B). 따라서 환자분 동 의하에 골절제술을 동반한 치은절제술을 재시행하였다. 즉 치은절제술 후 black triangle의 발생을 막기 위해 치간 유두보존판막을 전층으로 형성하였으며(Fig. 9C), 생물학 적폭경 확보를 위해 새로 형성된 치은연 $3 \mathrm{~mm}$ 하방까지 골절제술을 시행하였다(Fig. 9D). 마직막으로, 수직누상봉 합(Dafilon 6/0, B.Braun Surgical SA, Barcelona, Spain)으 로 마무리하였다. 변형된 입술 재위치술 시행 15 개월 후 미소 시 치은노출양은 없었으며(Fig. 10A), 골절제술을 동 반한 치은절제술 후 상악 전치부의 치은연의 위치가 잘 유 지되고 있었으며 심미성이 향상된 것을 관찰할 수 있었다 (Fig. 10B).

\section{고 찰}

미소 시 과도한 치은 노출을 보이는 환자는 대개 심미 적 주소를 호소한다. 여러 연구들에서 웃을 때 노출된 치 은양이 적을수록 더 심미적임을 보고하였다. Kokich 등 [16]은 일반인들의 경우에는 일반적으로 $4 \mathrm{~mm}$ 이상의 치 은 노출 시 비심미적으로 인식하는 경향이 있으며, $3 \mathrm{~mm}$ 까지 치은 노출은 심미적으로 받아들일 수 있다고 보고하 였다. 반면 치과의사들은 일반적으로 보다 더 적은 수치에 서도 비심미적으로 인식하며 미소 시 $1 \mathrm{~mm}$ 치은 노출까 지만 심미적이라 생각한다[8,17]. 이번 증례에서는 변형된 입술 재위치술 이후 두 증례에서는 치은 노출의 재발이 관 찰되지 않은 것으로 생각하였다. 첫 번째 증례에서 수술 1 년 후 $2 \mathrm{~mm}$ 치은 노출이 관찰되었다. 하지만 첫 번째 환 자 또한 현 상태에 심미적으로 높은 만족도를 보였으며 재 수술 필요성을 느끼지 않는다고 하였다.

수직적인 상악골 과성장 및 상순의 과활성도에 의해 발 생하는 gummy smile을 치료하기 위해 악교정수술을 대체 하는 다양한 치료방법이 제시되었다. Polo[18]는 보톡스 주입 

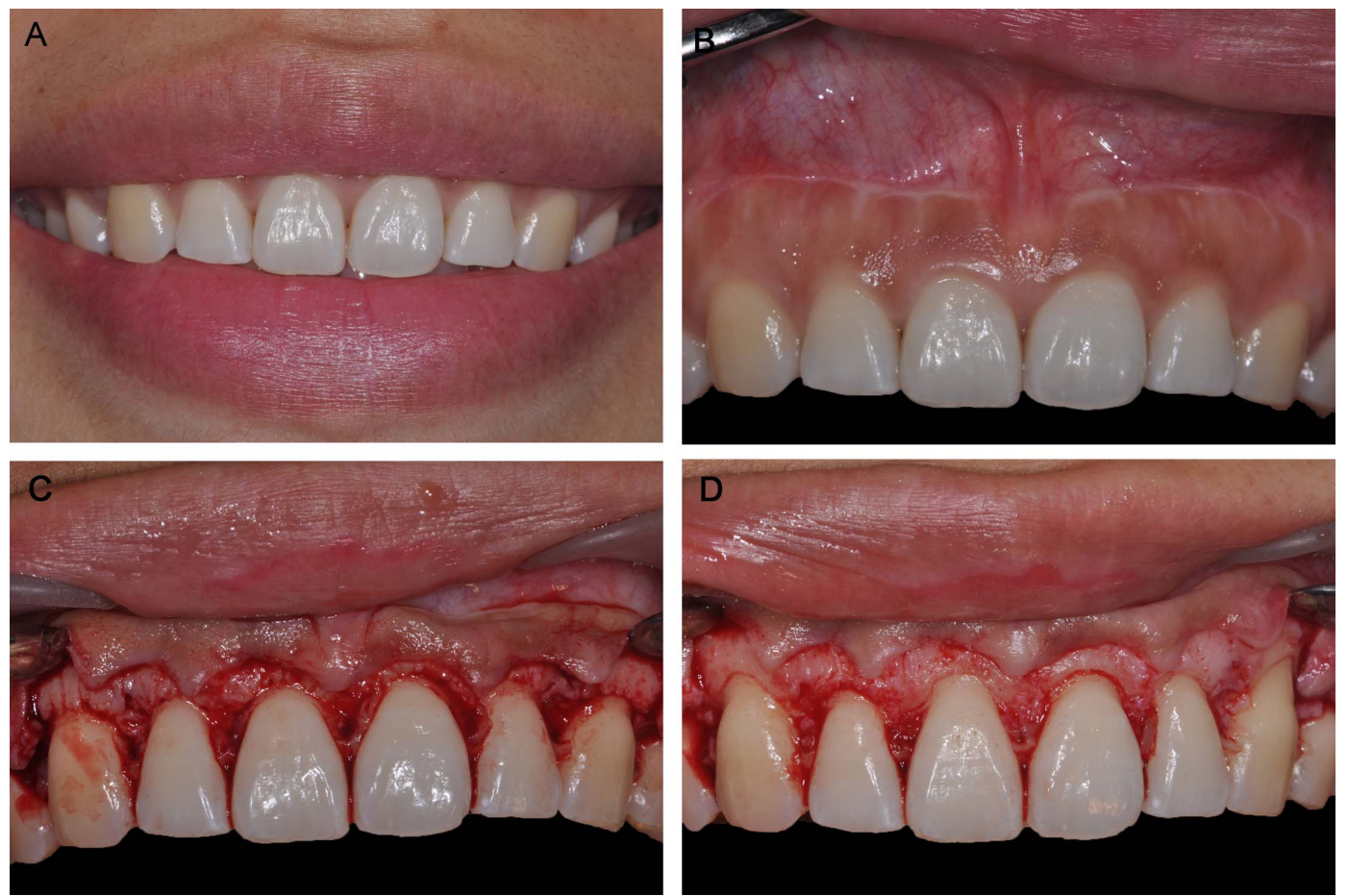

Fig. 9. (A) Extraoral view 3 months after surgery, (B) intraoral view 3 months after surgery, (C) Mucoperiosteal flap dissection, and (D) osteotomy and osteoplasty.
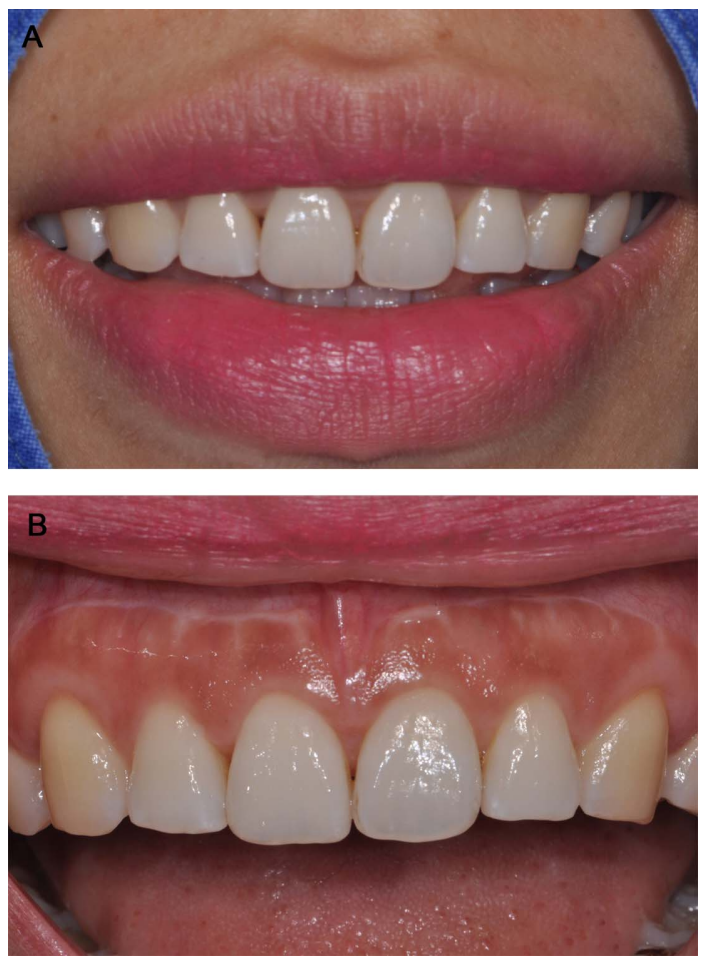

Fig. 10. (A) Extraoral view 15 months after lip repositioning and (B) intraoral view 15 months after lip repositioning.

2주 만에 치은노출양이 $5.2 \pm 1.4 \mathrm{~mm}$ 에서 $0.09 \pm 1.06 \mathrm{~mm}$ 까지 감소되었다고 보고하였다. 하지만 이후부터 점차적인 재
발 경향이 관찰되었고, 주입 30 32주 후에는 주입 전 상 태로 되돌아갔으며 예지성이 낮은 효과를 보였다. Gummy smile 치료를 위해 Ishida 등[19]은 순소대부터 윗입술올림 근까지 완전히 제거하는 근절제술을 통해 치은노출양이 $5.22 \pm 1.48 \mathrm{~mm}$ 에서 $1.91 \pm 1.50 \mathrm{~mm}$ 까지 감소되었다고 보고 하였다. 그러나 변형된 입술 재위치술에 비해 치은노출 감 소 효과는 비슷하면서도 감각마비와 같은 심각한 합병증 등이 보고되었다. 변형된 입술 재위치술을 시행한 위 증례 들에서는 술 후 가벼운 통증을 제외하고는 큰 불편감은 나 타나지 않았다. 치관변위판막술을 시행한 부위에서 scar가 형성된 것이 관찰되었지만 치근단 치조점막 부위에 위치 되어 있었기 때문에 환자분에게 심미적인 문제를 야기하 지 않았다. 변형된 입술 재위치술은 gummy smile 치료에 있어 상대적으로 덜 침습적인 수술이면서 예지성 있는 술 식이라 생각된다.

변형된 입술 재위치술을 사용하여 gummy smile 치료 시, 시간이 경과함에 따라 재발 경향이 관찰된다. 이번 증 례의 경우, 수술 1 2주 후부터 점차적인 재발 경향이 관찰 되었으나, 최대 15 개월 경과관찰기간까지도 세 명의 환자 들 모두 높은 심미적 만족도를 보였다. Silva 등[15]도 이 수술 시행 30 개월 후 이루어진 설문조사에서 대부분의 환 자들이 심미적으로 높은 만족도를 보였으며, 재수술 용의 가 높음을 보고하였다.

이번 증례 중에서 두 번째, 세 번째 증례에서는 심미적 
치관 확장술을 변형된 동반한 입술 재위치술을 시행했다. Lombardi[20]는 심미적인 상악 전치부 치아의 폭경/길이의 비율을 0.75-0.8 범위로 제안했는데, 이번 증례들의 경우는 모두 0.9 이상의 비율을 보여주었다. 폭경과 길이의 비율 이 0.6 이하에서는 좁고 긴 치아의 형태를 띄고, 0.8 이상 의 전치의 경우 크고 납작한 형태가 된다. 두 번째 증례의 상악중절치와 세 번째 증례의 견치 모두 길이가 부족한 상 황에서 이상적인 치아 형태를 보여주기 위해서 심미적 치 관 확장술이 동반되어야 했다. 과다 치은 노출 부위에 대 한 처치와 더불어 치아의 이상적인 폭경 대 길이의 비율 을 확보하는 것은 상악 전치부의 심미성 향상에 필요한 부 분이다.

이번 증례에서는 미소 시 과도한 치은 노출에 따른 비 심미적 문제를 호소하는 환자에게 있어, 변형된 입술 재위 치술을 하나의 치료방법으로 고려할 수 있음을 제시하였 다. 특히 변형된 수동적 맹출을 가진 환자에서는 심미적 치관연장술과 동반하여 치료할 경우, 더 높은 심미적 결과 를 얻을 수 있었다. 향후 이에 대한 좀 더 규모 있고 장기 간의 심도 깊은 연구가 필요하다고 생각된다.

\section{감사의 글}

This study was supported by research funds from Education and Cultural Foundation of College of Dentistry, Chosun University, 2017.

\section{Conflict of Interest}

The authors declare that they have no competing interests.

\section{ORCID}

$\begin{array}{ll}\text { Gwi-Hyeon Min } & 0000-0002-4583-993 X \\ \text { Sang-Joun Yu } & 0000-0001-8818-549 X \\ \text { Byung-Ock Kim } & 0000-0001-8952-617 X \\ \text { Won-Pyo Lee } & 0000-0003-1911-3454\end{array}$

\section{References}

1. Tjan AH, Miller GD. Some esthetic factors in a smile. J Prosthet Dent 1984;51:24-28. doi: 10.1016/S0022-3913 (84)80097-9.

2. Dong JK, Jin TH, Cho HW, Oh SC. The esthetics of the smile: a review of some recent studies. Int J Prosthodont 1999;12:9-19.

3. Geron S, Atalia W. Influence of sex on the perception of oral and smile esthetics with different gingival display and incisal plane inclination. Angle Orthod 2005;75: 778-784.

4. Coslet JG, Vanarsdall R, Weisgold A. Diagnosis and classification of delayed passive eruption of the dentogingival junction in the adult. Alpha Omegan 1977;70: 24-28.

5. Willmar K. On Le Fort I osteotomy; A follow-up study of 106 operated patients with maxillo-facial deformity. Scand J Plast Reconstr Surg 1974;12:1-68.

6. Peck S, Peck L, Kataja M. The gingival smile line. Angle Orthod 1992;62:91-100.

7. Goldman HM, Cohen DW. Periodontal therapy. St. Louis: Mosby; 1980. p.775.

8. Bhola M, Fairbairn PJ, Kolhatkar S, Chu SJ, Morris T, de Campos M. LipStaT: The lip stabilization techniqueindications and guidelines for case selection and classification of excessive gingival display. Int $\mathrm{J}$ Periodontics Restorative Dent 2015;35:549-559.

9. Rusenstein AM, Kostianovsky AS. Cirugia estetica de la malformacion de la sonrisa. Pren Med Argent 1973;60:952.

10. Gupta KK, Srivastava A, Singhal R, Srivastava S. An innovative cosmetic technique called lip repositioning. J Indian Soc Periodontol 2010;14:266-269. doi: 10.4103/ 0972-124X.76936.

11. Jacobs PJ, Jacobs BP. Lip repositioning with reversible trial for the management of excessive gingival display: a case series. Int J Periodontics Restorative Dent 2013;33: 169-175.

12. Gabrić Pandurić D, Blašković M, Brozović J, Sušić M. Surgical treatment of excessive gingival display using lip repositioning technique and laser gingivectomy as an alternative to orthognathic surgery. J Oral Maxillofac Surg 2014;72:404.e1-11. doi: 10.1016/j.joms.2013.10.016.

13. Muthukumar S, Natarajan S, Madhankumar S, Sampathkumar J. Lip repositioning surgery for correction of excessive gingival display. J Pharm Bioallied Sci 2015;7:794-796. doi: 10.4103/0975-7406.163567.

14. Mantovani MB, Souza EC, Marson FC, Corrêa GO, Progiante PS, Silva CO. Use of modified lip repositioning technique associated with esthetic crown lengthening for treatment of excessive gingival display: A case report of multiple etiologies. J Indian Soc Periodontol 2016;20:82-87. doi: 10.4103/0972-124X.164746.

15. Silva CO, Ribeiro-Júnior NV, Campos TV, Rodrigues JG, Tatakis DN. Excessive gingival display: treatment by a modified lip repositioning technique. J Clin Periodontol 2013;40:260-265. doi: 10.1111/jcpe.12046.

16. Kokich VO, Kokich VG, Kiyak HA. Perceptions of dental professionals and laypersons to altered dental esthet- 
Gwi-Hyeon Min et al.

ics: asymmetric and symmetric situations. Am J Orthod Dentofacial Orthop 2006;130:141-151. doi: 10.1016/j.ajodo. 2006.04.017.

17. Geron S, Atalia W. Influence of sex on the perception of oral and smile esthetics with different gingival display and incisal plane inclination. Angle Orthod 2005;75:778784.

18. Polo M. Botulinum toxin type A (Botox) for the neuromuscular correction of excessive gingival display on smiling (gummy smile). Am J Orthod Dentofacial Orthop
2008;133:195-203. doi: 10.1016/j.ajodo.2007.04.033.

19. Ishida LH, Ishida LC, Ishida J, Grynglas J, Alonso N, Ferreira MC. Myotomy of the levator labii superioris muscle and lip repositioning: a combined approach for the correction of gummy smile. Plast Reconstr Surg 2010;126:1014-1019. doi: 10.1097/PRS.0b013e3181e3b6d4.

20. Lombardi RE. The principles of visual perception and their clinical application to denture esthetics. J prosthet Dent 1973;29:358-382. doi: 10.1016/S0022-3913(73)80013-7. 